\title{
cansm \\ Comparing Permitted Emissions to Atmospheric Observations of Hydrocarbons in the Eagle Ford Shale Suggests Permit Violations
}

\author{
Joel Holliman ${ }^{1}\left(\mathbb{D}\right.$ and Gunnar W. Schade ${ }^{2, *}$ \\ 1 College of Geosciences Environmental Programs, College Station, TX 77843, USA; hollimanjoel2@gmail.com \\ 2 Department of Atmospheric Sciences, Texas A\&M University, College Station, TX 77843, USA \\ * Correspondence: gws@geos.tamu.edu; Tel.: +1-979-845-0633
}

Citation: Holliman, J.; Schade, G.W. Comparing Permitted Emissions to Atmospheric Observations of Hydrocarbons in the Eagle Ford Shale Suggests Permit Violations. Energies 2021, 14, 780. https://doi.org/ $10.3390 /$ en14030780

Academic Editor: Alexis Laurent Received: 27 December 2020

Accepted: 28 January 2021

Published: 2 February 2021

Publisher's Note: MDPI stays neutral with regard to jurisdictional claims in published maps and institutional affiliations.

Copyright: (c) 2021 by the authors. Licensee MDPI, Basel, Switzerland. This article is an open access article distributed under the terms and conditions of the Creative Commons Attribution (CC BY) license (https:// creativecommons.org/licenses/by/ $4.0 /)$.

\begin{abstract}
The recent decade's rapid unconventional oil and gas development in the Eagle Ford of south-central Texas has caused increased hydrocarbon emissions, which we have previously analyzed using data from a Texas Commission on Environmental Quality air quality monitoring station located downwind of the shale area. Here, we expand our previous top-down emissions estimate and compare it to an estimated regional emissions maximum based on (i) individual facility permits for volatile organic compound (VOC) emissions, (ii) reported point source emissions of VOCs, (iii) traffic-related emissions, and (iv) upset emissions. This largely permit-based emissions estimate accounted, on average, for $86 \%$ of the median calculated emissions of $C_{3}-C_{6}$-hydrocarbons at the monitor. Since the measurement-based emissions encompass a smaller section of the shale than the calculated maximum permitted emissions, this strongly suggests that the actual emissions from oil and gas operations in this part of the Eagle Ford exceeded their permitted allowance. Possible explanations for the discrepancy include emissions from abandoned wells and high volumes of venting versus flaring. Using other recent observations, such as large fractions of unlit flares in the Permian shale basin, we suggest that the excessive venting of raw gas is a likely explanation. States such as Texas with significant oil gas production will need to require better accounting of emissions if they are to move towards a more sustainable energy economy.
\end{abstract}

Keywords: shale oil and gas; emissions permitting; atmospheric measurements; excess VOC emissions

\section{Introduction}

Technological advances in petroleum recovery, such as horizontal drilling and hydraulic fracturing, have made fossil oil and gas production possible from previously untapped shale reservoirs. Prior studies have shown this unconventional oil and gas (UOG) development to contribute substantially to the regional emissions and concentrations of greenhouse gases and air pollutants [1-7]. The Eagle Ford shale (EFS), an extensive shale formation in South-Central Texas, has undergone UOG development for over a decade, including, due to a strong north-south gas-oil ratio gradient, production dominated by oil in the northern portion of the shale and by gas in its southern portion. In a previous study [8], volatile organic compound (VOC) emissions in the intensely developed central section of the EFS were estimated using meteorological and ethane enhancement data from a Texas Commission on Environmental Quality (TCEQ) monitoring station located downwind of the EFS in Floresville, TX, south-southeast of San Antonio. VOCs are of concern due to their ozone formation potential, especially in and near urban areas. Legally, i.e., for permitting processes, VOCs exclude methane and ethane. In shale oil and gas production areas, VOCs tend to be dominated by saturated, short-chain hydrocarbons. While atmospheric ozone formation from hydrocarbons in the mostly rural EFS area is likely $\mathrm{NO}_{\mathrm{x}}$-limited [9], and may thus be comparatively small, conurbations, such as the 
greater San Antonio area (Bexar county), where sufficient $\mathrm{NO}_{\mathrm{x}}$ is present, could see more substantial air quality degradation due to the transport of these VOCs from the EFS. In 2018, Bexar County was categorized as a nonattainment for the eight-hour National Ambient Air Quality Standard for the ozone of $70 \mathrm{ppb}$. Previous studies have estimated the Eagle Ford's contribution to Bexar County's summer ozone maximum concentrations to be between $0.1-2.5 \mathrm{ppb}[9,10]$.

In our previous study [8], we estimated the alkane emissions from a central section of the EFS for a set of 68 days in 2014 to 2015, during which winds at the Floresville monitoring site were from the south-southeast, originating from the Gulf of Mexico. These air masses contained alkanes emitted from oil and gas exploration activity in Texas counties located between Floresville and the Gulf of Mexico, with the gulf coast air close to clean background levels. Considering the emission levels we calculated, we wondered how they compared with the permitted total VOC emission rate by the TCEQ in counties upwind of the Floresville monitoring station. In addition to these permitted emissions, the state also tracks accidental releases from point sources, and we need to consider other sources, especially area sources such as traffic emissions. Thus, we present a compilation of the expected versus observable emissions of VOCs for a specific Texas setting with convenient databases. Note that this should not be mistaken with a more detailed bottom-up calculation of emissions based on the activity factors of known emission sources in the industry. Instead, the purpose of this study was to provide a comparison of the legal limits, with the expectation of finding that there are no widespread permit violations.

\section{Methods}

VOC emissions in the Eagle Ford were estimated in the Roest study using the TCEQ air quality monitoring stations in Corpus Christi, TX, and Floresville, TX, as the EFS is located downwind of Corpus Christi and upwind of Floresville. From this study, the median emission estimates of ten alkanes (propane, n-butane, isobutane, n-pentane, isopentane, n-hexane, cyclopentane, cyclohexane, and methyl-cyclohexane), extended from the original study [8], were included in a total VOC emission estimate for this part of the Eagle Ford, spanning from July 2013 to December 2015. As previous studies have shown, these are all alkanes emitted from oil and gas operations in shale exploration areas. All showed significantly higher abundances at the downwind monitor, and their respective calculated emissions were dominated ( $83 \%$ by mass) by propane and butanes. They occurred in a large upwind area from the air quality monitor, which overlaps mostly with Karnes County but, marginally, also with neighboring and further distant counties [8].

These actual emissions can be compared with county-based numbers from two known major sources: (1) oil and gas operations in the EFS, as assessed via point source inventories, upset emission reports, and air permits issued by the TCEQ and (2) traffic-related emissions as assessed in a previous study by the Texas Transportation Institute (TTI). The emissions of short-chain alkanes originating from other, nongeological sources were assumed to be negligible, as the EFS is a predominately rural area with limited anthropogenic sources. Only point source records and air permits from counties atop the EFS and upwind of the Floresville monitoring station were accounted for in this inventory. While only Karnes, Live Oak, De Witt, and Lavaca counties sit atop the Eagle Ford, Refugio, Bee, and Goliad Counties were included, as they can be upwind of the Floresville monitoring station and may, thus, contribute to the observed atmospheric concentrations of the VOCs. This complete inclusion of counties, some of which are very distant $(>120 \mathrm{~km})$ from the monitoring station, likely overestimates their contribution to the VOC concentrations observed in Floresville. However, a more accurate estimate using dispersion modeling and permit locations was beyond the scope of this limited study.

The point source emissions were assessed using the TCEQ Point Source Inventory. Annual, statewide summaries of the Point Source Inventory are published by the TCEQ, available at https://www.tceq.texas.gov/airquality/point-source-ei/psei.html. Industrial sites are required to report emissions annually if they exceed the applicability levels listed 
in the Texas Administrative Code (TAC) Chapter 30 Rule 101.10 (Emission Inventory Requirements). Major source facilities with a site-specific permit (Federal Operating Permits, "Title V") are required to report VOC emissions directly to the TCEQ. Any facility with the potential to emit 100 tons per year (tpy; one short ton is equal to $907.2 \mathrm{~kg}$ ) of any contaminant is required to report emissions.

Upset emissions, defined as an unplanned and unavoidable breakdown or deviation of a process or operation that results in unauthorized emissions, also require reporting to the TCEQ. The state inventory was used here and filtered for applicable counties only. Upset emissions were estimated using the TCEQ Air Emission Event Report Database, available at https://www2.tceq.texas.gov/oce/eer/. The VOC emission events occurring in the subject counties between 1 July 2013 and 31 December 2015 were summed and added. Emission events of non-VOC species were not included. Raw gas emission events were partially included, because the TCEQ defines ethane and methane as non-VOCs. Thus, all "natural gas" emission events were included at only a 5\% mass fraction to include the portion of gas with carbon chain lengths greater or equal to three. In addition, due to the semiquantitative nature of emissions reporting for such upset emission events, all TCEQ VOC point source emission inventories were included with a presumed $100 \%$ margin of error.

The VOC contributions from nonmajor source oil and gas sites were estimated using the Air Permits Index, which contains New Source Review permits such as, Permit by Rule (PBR), Standard Permit, (STDPMT), Standard Exemption, and De Minimis. To streamline the permitting process, PBR permits authorize emissions for activities that are above the de minimis levels of emissions but lower than the standard permit options. PBR permits allow for 25 tpy of VOC emissions (TAC Chapter 30 Rule §106.4) per site and are the dominant air permits in the EFS. They present a potential regulatory failure, as they require only precalculated site emissions and no monitoring or reporting, presuming that the actual emissions will never exceed the specified limit in the PBR.

The next most important permits in the counties of concern are Standard Permits. A STDPMT allows for 250 tpy of VOC emissions. Both PBR and STDPMT VOC allowances are for the total actual site emissions (pers. comm. with TCEQ, 2018), which includes VOC emissions resulting from processes such as venting and flaring, which are partially regulated by the Texas Railroad Commission. It was assumed that there is an up to $10 \%$ uncertainty (one standard deviation) associated with the permit data.

Some Standard Exemption permits are still effective but are rare. Sites that did qualify for a Standard Exemption permit were assumed to be out of commission due to age. No De Minimis permits were issued. Air permits must have been issued before July 2015 to be relevant to this study. Permits issued by the TCEQ are available publicly at https: / / records.tceq.texas.gov/cs/idcplg?IdcService=TCEQ_SEARCH.

Lastly, vehicle traffic is the other expected major source of VOC emissions in the EFS. In their 2015 report to TCEQ, the TTI [11] estimated the mobile source VOC emissions for counties in the Eagle Ford based on a summer weekday traffic scenario. Some upwind counties included in this study are not included in the TTI report, as they were not considered by the TTI to be a part of the EFS area. Nevertheless, we included the TTI estimates of traffic emissions in this study but conservatively assumed a 50\% margin of error based on the limited accuracy and biases of such modeled emission rates [12].

\section{Results and Discussion}

In total, the permitted, reported, and traffic emissions in the assessed region accounted for $76 \mathrm{Gg} \mathrm{yr}^{-1}$ (one sd range was $65-87 \mathrm{Gg} \mathrm{yr}^{-1}$ ), visualized in Figure 1 and listed in more detail in Table 1 . This represented between $79 \%$ and $98 \%$ of the median calculated emissions of $88 \mathrm{Gg} \mathrm{yr}^{-1}$ (interquartile range (IQR) 59-146 G yr${ }^{-1}$ ), and the discrepancy was significant at the $95 \%$ level when equating the range and IQR, respectively, to a one standard deviation error estimate of each dataset. Upset emissions, i.e., nonpermitted 
emission events (EE) reported to the state (TAC 30, Chapter 101, Rule \$101.201) contributed an additional $0.25 \mathrm{Gg} \mathrm{yr}^{-1}$, a negligible amount compared to permitted emissions.

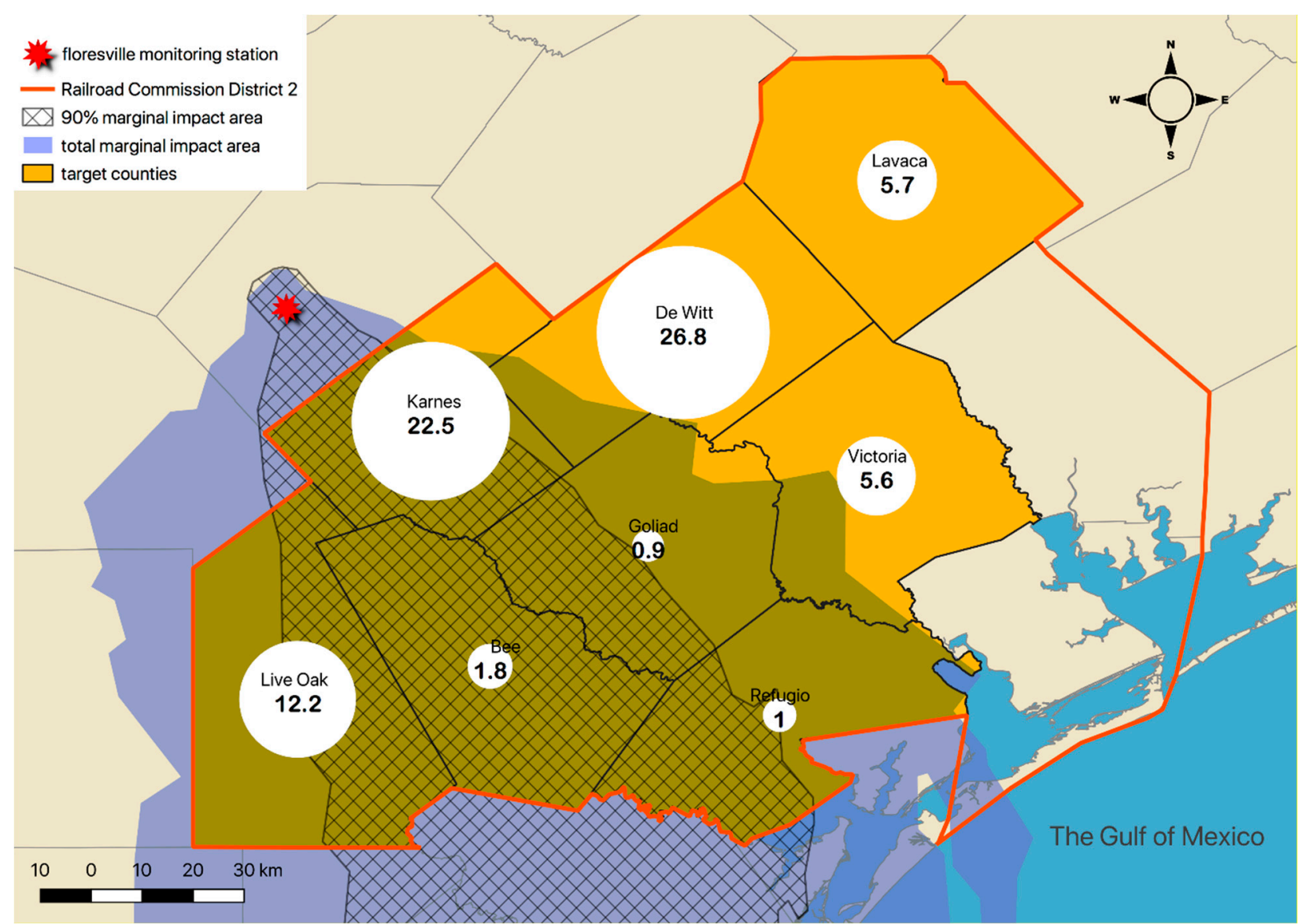

Figure 1. Per county volatile organic compound (VOC) emission allowances in Gg per year compared to an example area of the atmospheric calculations from our prior study (30 July 2014) [8]. The hatched area encloses the origin of $90 \%$ of the emissions that occurred over the prior $12 \mathrm{~h}$ impacting the monitor that afternoon; the light blue area approximates the respective total marginal impact area over that time frame.

Table 1. County contributions to the permitted, reported, traffic related, and upset emissions. PBR: Permit by Rule, and STDPMT: standard permit.

\begin{tabular}{cccccccc}
\hline County & $\begin{array}{c}\text { \# of } \\
\text { PBR } \\
\text { Issued }\end{array}$ & $\begin{array}{c}\text { \# of } \\
\text { STDPMT } \\
\text { Issued }\end{array}$ & $\begin{array}{c}\text { Total } \\
\text { Permitted } \\
\text { Emissions } \\
\mathbf{( G g / y r )}\end{array}$ & $\begin{array}{c}\text { Reported } \\
\text { Emissions } \\
(\mathbf{G g} / \mathbf{y r})\end{array}$ & $\begin{array}{c}\text { Traffic } \\
\text { Related } \\
\text { Emissions } \\
\mathbf{( G g / y r )}\end{array}$ & $\begin{array}{c}\text { Upset } \\
\text { Emis- } \\
\text { sions } \\
(\mathbf{G g} / \mathbf{y r})\end{array}$ & $\begin{array}{c}\text { Total } \\
\mathbf{( G g / y r )}\end{array}$ \\
\hline Karnes & 462 & 186 & 21.2 & 0.6 & 0.6 & 0.1 & 22.5 \\
de Witt & 318 & 251 & 25.8 & 0.2 & 0.7 & 0.04 & 26.8 \\
Live oak & 262 & 91 & 10.7 & 0.6 & 0.7 & 0.03 & 12.0 \\
Lavaca & 139 & 38 & 4.7 & 0.2 & 0.7 & 0.02 & 5.7 \\
Refugio & 62 & 4 & 0.9 & 0.0 & $\mathrm{~N} / \mathrm{A}$ & 0.02 & 1.0 \\
Bee & 47 & 7 & 1.1 & 0.1 & 0.6 & 0.0 & 1.8 \\
Goliad & 27 & 1 & 0.3 & 0.5 & $\mathrm{~N} / \mathrm{A}$ & 0.0 & 0.9 \\
Victoria & 17 & 1 & 0.2 & 0.7 & 4.5 & 0.04 & 5.6 \\
Total & $\mathbf{1 3 3 4}$ & $\mathbf{5 7 9}$ & $\mathbf{6 5}$ & $\mathbf{3 . 0}$ & $\mathbf{8 . 0}$ & $\mathbf{0 . 2 5}$ & $\mathbf{7 6 . 2}$ \\
\hline
\end{tabular}

The upwind impact areas overlapped with most of the selected counties for this study, except rarely with Lavaca County toward the east of the monitor. A typical 12-h upwind $90 \%$ impact area was of the order of 15,000 square kilometers, similar to the combined sizes of Karnes, Dewitt, Life Oak, Refugio, Bee, Victoria, and Goliad Counties $\left(16,000 \mathrm{~km}^{2}\right)$. The far dominant impact county in all cases was Karnes County, directly upwind of 
the monitor, with the cumulative permitted, traffic, and upset emissions (22.5 $\left.\mathrm{Gg} \mathrm{yr}^{-1}\right)$ representing approximately one-quarter of the calculated emissions.

Viewed holistically, these results appear unusual, considering that (i) the long-term measurement-based emissions estimate is most certainly an underestimate, considering the atmospheric chemical losses during transport, especially for emissions of compounds not included due to their higher atmospheric reactivity, and (ii) emissions permitted via PBR and STDPMT are dominant, and one would normally assume that the actual emissions are lower than the maximum permitted via the online permitting process. This is because the permit-seeking entity demonstrates via standardized engineering calculations for its application that the emissions are not expected to exceed the limit of the permit applied for, e.g., 25 tpy for a PBR. Casual inspections of such permits reveals that these calculated emissions are generally much lower than the maximum permitted, providing the operator some buffer before a permit may be violated during routine operations, even if the initial calculations underestimated the potential emissions.

The discrepancy between the calculated emissions based on the downwind hydrocarbon observations and emissions known and permitted by state agencies could be due to several factors. First, an underestimation of production by the operators: On-site processes that generate VOC emissions (tank flashing, pneumatic valves, venting, leaks, etc.) are at least partially dependent on production volumes, and an underestimation of future productions during the air permit application process could lead to a future violation of the permitted VOC emission limits. Second, unusually high hydrocarbon emissions from legacy oil and gas wells: Although no longer in production, abandoned wells may contribute substantially to regional emissions [13]. Third, unexpectedly high rates of venting and flaring: In an independent work, we showed that the reported venting and flaring volumes in Texas are substantially lower than what is observable via satellite [14]. One possible explanation for this discrepancy is malfunctioning, unlit flares, which have been documented extensively by environmental organizations [15,16]. These emissions, dominated by methane, are not listed during the permitting process and could account for much higher actual than permitted VOC emissions. For instance, assuming a typical oil production site flare burning 100,000 $\mathrm{mcf}(1 \mathrm{mcf}=1000$ cubic feet $)$ of associated gas ("casinghead gas" at a density of $0.05 \mathrm{lbs}$. per cubic foot) per year, consisting of $5 \%$ VOCs by mass were malfunctioning $20 \%$ of the time, this would translate into 25 -tpy VOC emissions. That is equal to the permitted emissions as per the PBR, leaving no room for other emissions without violating the permit.

\section{Conclusions and Policy Implications}

We demonstrated that the actual emissions of VOCs in the Central Eagle Ford shale likely exceeded permitted emissions from the oil and gas industry during the period from mid-2013 to the end of 2015. This finding was unexpected and was made more significant considering that this maximum emissions figure likely overestimated the relevant upwind VOC emissions as compared to the calculated emissions based on atmospheric observations. This is because the permit-dominated estimate included counties both peripheral and distant to the monitoring station. Distant counties (Refugio, Bee, Goliad, and Victoria) contributed only a small portion of their total emissions to the concentrations observed downwind at the Floresville monitoring station due to chemical removal and dispersion. However, in this study, permitted, reported, and traffic-related emissions from both directly upwind and these distant counties were included in their entirety. Similarly, counties that were not southeast of the monitoring station (mostly Lavaca) and, thus, not directly upwind were equally unlikely to contribute all of their emissions to the observed concentrations at the Floresville monitor. More likely, the majority of emissions observed at the Floresville monitor are from neighboring Karnes County, for which the total permitted, upset, and traffic emissions represent only one-quarter of the calculated emissions based upon the atmospheric measurements. 
While this strongly suggests that the air emission permits were (and possibly still are) violated on an area basis, the emissions events, i.e., typically, accidental emissions exceeding certain threshold amounts and reported to the TCEQ by the industry, cannot account for the difference. More likely, therefore, the identified excess emissions came from a more routine industrial process, such as flaring. While flare malfunctions technically need to be reported as emission events, depending on the raw emission amounts, companies rarely monitor their flare operations. Standard permits require regular-typically dailyflare operation assessments, but the only requirement for sites with a PBR permit is to assure a "continuously burning pilot or other automatic ignition system that assures gas ignition", unless the gas combusted contains significant sulfur amounts (TAC Chapter 30, Rule §106.492). Increased flaring volumes, facilitated by PBR permits, have become criticized for environmental reasons and for the fact that enormous amounts of gas-in Texas, roughly the equivalent of its annual residential use-are wasted. The oil and gas industry's preferred solution to reduce flaring, i.e., an increased pipeline capacity, especially toward new LNG export facilities at the Gulf of Mexico, did not decrease the pre-pandemic US flaring volumes, which, instead, kept increasing with the rapidly increasing shale oil production. Thus, arguably, the promoted pipeline solution effectively acts as an infrastructure subsidy if flaring is not regulated otherwise [16]. Furthermore, growing antiflaring notions and/or policies might push oil production companies toward venting rather than flaring, since the former cannot be detected from space [17]. If this were already true, it would explain not only why unlit flares are common but, also, why the satellite flaring data showed apparently higher flaring volumes than reported for two Texas oil production basins [14]. The latter may result from a satellite IR radiation sensor calibration that is based upon nationally reported venting and flaring volumes and presumes all reported volumes are for flared instead of vented gas [18], since much venting is illegal. Thus, aside from the obvious underestimation of methane emissions [19], venting also causes much higher VOC emissions-including unnecessary air toxics emissions, such as benzene-because raw associated gas typically contains several percent higher hydrocarbons.

In more general terms, whether driven by flaring or not, the unexpected discrepancy between large-scale permitted and observable emissions questions the practicality of permits such as PBRs, which are not verified for compliance by the regulatory agency. Given a growing consensus that reported oil and gas industry methane emissions are of an order of $60 \%$ lower than actual emissions [2], a similar conclusion can be drawn for VOCs, which could be the driver for widespread PBR permit exceedances.

To address this issue, more information about emissions and more goal-oriented policies to discourage waste in the form of flaring are needed. For instance, the Texas Railroad Commission's practice to allow the reporting of venting and flaring as a single number was recently revised to provide flaring and venting data independently. This will further improve satellite flaring volume estimates and, thus, allow for a more precise accounting of the associated environmental and economic costs. This more precise accounting will also be necessary to support the discussion of how to allocate future energy subsidies and determine the benefit, if any, of investments in an increased pipeline capacity.

Furthermore, a stronger incentive to use gas instead of waste gas could be achieved with a fee on all venting and flaring volumes. Volumes of vented and flared gas represent an economically significant energy equivalent, and changes in the states' regulations of venting and flaring have a great potential to both reduce the emission of greenhouse gases and conserve significant quantities of energy-rich fossil gas. In moving towards a more sustainable energy economy, part of several UN sustainable development goals (SDGs), states such as Texas with significant UOG production have the potential to set the stage in both the reduction of greenhouse gas emissions and in energy conservation. Meeting the UN sustainability goals in the United States-specifically, the goals of sustainable energy production and reduction of waste (SDGs 7 and 12) -will depend on the regulatory participation of oil and gas-producing states. With over $40 \%$ of the US crude oil production occurring in Texas [20], initiating state regulatory practices that discourage waste and 
improve energy efficiency will be necessary if the US is to attain a more sustainable energy economy. Recently, the French trading firm Engie, owned, in part, by the French government, delayed a purchase of liquid natural gas from the NextDecades facility in Brownsville, Texas, due to a perceived lack of regulation on methane venting occurring in the Permian Basin [21]. Clearly, unsustainable policies can have consequences.

Author Contributions: Conceptualization, G.W.S.; methodology and validation, G.W.S. and J.H.; analysis and data curation, J.H.; writing-original draft preparation, J.H.; writing-review and editing, G.W.S.; visualization, J.H.; and supervision, G.W.S. All authors have read and agreed to the published version of the manuscript.

Funding: This research received no external funding. It was partially supported by an internal undergraduate research grant from the College of Geosciences, Texas A\&M University, to J.H.

Data Availability Statement: Permit and other data used in this manuscript is available through the Texas Data Repository at https://doi.org/10.18738/T8/HBAPBB.

Acknowledgments: The authors thank Geoff Roest for providing an extended hydrocarbon emissions database for use in this comparison.

Conflicts of Interest: The authors declare no conflict of interest.

\section{References}

1. Allen, D.T. Emissions from oil and gas operations in the United States and their air quality implications. J. Air Waste Manag. Assoc. 2016, 66, 549-575. [CrossRef] [PubMed]

2. Alvarez, R.A.; Zavala-Araiza, D.; Lyon, D.R.; Allen, D.T.; Barkley, Z.R.; Brandt, A.R.; Davis, K.J.; Herndon, S.C.; Jacob, D.J.; Karion, A.; et al. Assessment of methane emissions from the U.S. oil and gas supply chain. Science 2018, 361, 186-188. [CrossRef] [PubMed]

3. Schade, G.W.; Roest, G.S. Source apportionment of non-methane hydrocarbons, NOx and H2S data from a central monitoring station in the Eagle Ford shale, Texas. Elem. Sci. Anthr. 2018, 6, 35. [CrossRef]

4. Littlefield, J.A.; Marriott, J.; Schivley, G.A.; Skone, T.J. Synthesis of recent ground-level methane emission measurements from the U.S. natural gas supply chain. J. Clean. Prod. 2017, 148, 118-126. [CrossRef]

5. Douglas Goetz, J.; Avery, A.; Werden, B.; Floerchinger, C.; Fortner, E.C.; Wormhoudt, J.; Massoli, P.; Herndon, S.C.; Kolb, C.E.; Knighton, W.B.; et al. Analysis of local-scale background concentrations of methane and other gas-phase species in the Marcellus Shale. Elem. Sci. Anthr. 2017, 5. [CrossRef]

6. Field, R.A.; Soltis, J.; McCarthy, M.C.; Murphy, S.; Montague, D.C. Influence of oil and gas field operations on spatial and temporal distributions of atmospheric non-methane hydrocarbons and their effect on ozone formation in winter. Atmos. Chem. Phys. 2015, 15, 3527-3542. [CrossRef]

7. Halliday, H.S.; Thompson, A.M.; Wisthaler, A.; Blake, D.R.; Hornbrook, R.S.; Mikoviny, T.; Müller, M.; Eichler, P.; Apel, E.C.; Hills, A.J. Atmospheric benzene observations from oil and gas production in the Denver-Julesburg Basin in July and August 2014. J. Geophys. Res. Atmos. 2016, 121, 11055-11074. [CrossRef]

8. Roest, G.; Schade, G. Quantifying alkane emissions in the Eagle Ford Shale using boundary layer enhancement. Atmos. Chem. Phys. 2017, 17, 11163-11176. [CrossRef]

9. Pacsi, A.P.; Kimura, Y.; McGaughey, G.; McDonald-Buller, E.C.; Allen, D.T. Regional Ozone Impacts of Increased Natural Gas Use in the Texas Power Sector and Development in the Eagle Ford Shale. Environ. Sci. Technol. 2015, 49, 3966-3973. [CrossRef]

10. AACOG Natural Resources Department. Ozone Analysis June 2006 Photochemical Modeling Episode; AACOG: San Antonio, TX, USA, 2015.

11. Texas Transportation Institute. Estimation of On-Road Mobile Source Emission Associated with Oil and Gas Development in the Eagle Ford Shale Area; 582-15-52612-21; TTI: College Station, TX, USA, 2015; p. 174.

12. Kota, S.H.; Park, C.; Hale, M.C.; Werner, N.D.; Schade, G.W.; Ying, Q. Estimation of VOC emission factors from flux measurements using a receptor model and footprint analysis. Atmos. Environ. 2014, 82, 24-35. [CrossRef]

13. Kang, M.; Christian, S.; Celia, M.A.; Mauzerall, D.L.; Bill, M.; Miller, A.R.; Chen, Y.; Conrad, M.E.; Darrah, T.H.; Jackson, R.B. Identification and characterization of high methane-emitting abandoned oil and gas wells. Proc. Natl. Acad. Sci. USA 2016, 113, 13636-13641. [CrossRef] [PubMed]

14. Willyard, K.A.; Schade, G.W. Flaring in two Texas shale areas: Comparison of bottom-up with top-down volume estimates for 2012 to 2015. Sci. Total Environ. 2019, 691, 243-251. [CrossRef] [PubMed]

15. EDF. Flaring-Aerial Survey Results. Available online: http:/ / permianmap.org/flaring-emissions / (accessed on 4 June 2020).

16. Wilson, S. Pollution on Purpose? Unlit Flares in TX Harm Health \& Climate-during a Public Health \& Climate Crisis. EARTHWorks, Ed. Available online: https:/ / earthworks.org/blog/pollution-on-purpose/ (accessed on 26 January 2021). 
17. Calel, R.; Mahdavi, P. Opinion: The unintended consequences of antiflaring policies-And measures for mitigation. Proc. Natl. Acad. Sci. USA 2020, 10. [CrossRef] [PubMed]

18. Elvidge, C.D.; Zhizhin, M.; Baugh, K.; Hsu, F.C.; Ghosh, T. Methods for Global Survey of Natural Gas Flaring from Visible Infrared Imaging Radiometer Suite Data. Energies 2016, 9, 14. [CrossRef]

19. Zhang, Y.; Gautam, R.; Pandey, S.; Omara, M.; Maasakkers, J.D.; Sadavarte, P.; Lyon, D.; Nesser, H.; Sulprizio, M.P.; Varon, D.J.; et al. Quantifying methane emissions from the largest oil-producing basin in the United States from space. Sci. Adv. 2020, 6, eaaz5120. [CrossRef] [PubMed]

20. US Energy Information Administration. Oil and Petroleum Products Explained-Where Our Oil Comes from. Available online: https:/ / www.eia.gov/energyexplained/oil-and-petroleum-products/where-our-oil-comes-from.php (accessed on 26 January 2021).

21. Lefebvre, B. French Government Blocks U.S. LNG Deal as too Dirty. Politico. Available online: https://www.politico.com/news / 2020/10/21/ french-government-blocks-lng-deal-431028 (accessed on 26 January 2021). 